\title{
Temporal Causality and Dynamics of Financial Development, Trade Openness and Economic Growth in Vector Auto Regression (VAR) for Bangladesh, 1974-2003: Implication for Poverty Reduction
}

\author{
A.F.M. Kamrul Hassan \\ M. Rafiqul Islam
}

\begin{abstract}
This paper examines whether financial development and openness to international trade can play any positive role in reducing poverty in Bangladesh through their growth enhancing effect. The paper takes granted that growth reduce poverty and makes econometric test to ascertain whether financial development and trade openness cause growth. Standard Granger-causality test is employed for this purpose. Variables are found first difference stationary without having any co-integrating relationship as reported by Johansen co-integration test. As such Granger-causality test is carried out in first difference VAR. The paper does not find any causal relationship between trade openness and growth, and financial development and growth. This implies that financial development and trade openness do not reduce poverty through their effect on growth. However, bi-directional causal link evidenced between financial development and trade openness indicates that these two can contribute to poverty reduction directly through their mutual effect on each other.
\end{abstract}

THERE IS A GROWING BODY of literature that consider financial development and openness to international trade as important policy options for reducing poverty in developing countries. The argument is that financial development and trade openness foster economic growth and economic growth, in turn, raise income of the poor and reduce poverty. Therefore, in order for financial development and trade openness to have poverty reducing impact, positive casual effects should run from these two macroeconomic aspects to economic growth.

Causal relationships between finance and growth, and growth and trade have been the subject of a voluminous body of theoretical as well as empirical research. Research works mainly focused on the direction of causality between these macro aspects without establishing any unique solution. McKinnon (1973) and Shaw (1973) first identify the role of financial development in the process of economic development. They suggest that financial development is an essential ingredient of the process of capital accumulation as reflected in savings and investments and their productivity. King and Levine (1993b) emphasizes that efficiency-enhancing aspects of financial sector is more important than the impact on the amount of investment. But the economists do not share this view unanimously.

For example, Nobel Prize winner economists disagree about the impact of financial sector on economic growth. Some do not even consider finance worth discussing (Levine 2003). A collection of essays by the "pioneers of development economics"-including three winners of the Nobel Prize in Economics-does not discuss finance (Meier and Seers 1984). On the other hand, extremely opposite view is expressed by another Nobel Prize winner Miller (1998) when he remarks "that financial markets contribute to economic growth is a proposition almost too obvious for serious discussion". As a third view Nobel Laureate Robert Lucas (1988) holds that the role of finance in economic growth has been "over-stressed" by the growth literature. Despite these differing views, literature on financegrowth nexus is growing. Thus there is heterogeneity of views about the role of finance in economic growth.

The whole array of literature on finance-growth relationship can be divided into two broad categories: Supply-leading hypothesis and 'Demand following hypothesis. According to 'Supplyleading' hypothesis finance is a contributing factor in economic growth. Financial sector transfers resources from the traditional low-growth sector (for example agriculture and land rents) to modern high growth sectors, and promotes and stimulates entrepreneurial responses in these modern sectors. 


\section{The Journal of Nepalese Business Studies}

This implies that creation of financial institutions and the supply of financial services are well in advance of demand for them. The findings of McKinnon (1973), Shaw (1973), King and Levine (1992, 1993a, 1993b, 1993c) support this proposition. Second group of literature, dubbed as 'Demand-following' hypothesis, views finance as dependent upon economic growth, that is, the creation of modern financial institutions and financial services are a response to the demand for these services by investors and savers in the real economy (Patrick 1966). The financial system adapts itself to the financial needs of the real sector and fits in with its autonomous development, playing a relatively passive role in the growth process (Berthelemy and Varoudakis 1996).

Two other views, though not dominating, tried to offer different explanations of the relationship between finance and growth. Graff (2001) claims that finance and growth are not causally related. According to this view, while modern economic growth is governed by real sector, the financial development is rooted in the history of financial institutions. Garcia and Liu (1999) explain a reciprocal relationship between financial development and economic growth. According to them economic growth makes the development of financial institutions profitable. The establishment of an efficient financial system in turn permits faster economic growth. So there is no clear-cut answer to the question on the cause and effect.

The same type of debate revolves around the relationship between trade openness and economic growth. The Classical and Neo-Classical economists believed that participation in trade openness could be a strong positive force for economic growth and development. This positive role of trade openness in economic growth led countries around the world to integrate domestic economy with rest of the world in the form of increased export and import. In the literature of international economics it is argued that trade openness leads to economic growth by increasing a country's specialization and productivity level. Although the relationship between trade and growth has been the subject of a voluminous body of literature, there is a significant amount of disagreement on the direction of causality. The extent to which trade openness engenders economic growth has been intensely debated in literature. Guillaumet and Richaud (2001) pointed out that this disagreement centers around two main ideas:

1. National development is an indispensable preliminary to openness. Foreign trade is a step that comes after the agricultural, and in most cases, the industrial development of the nation.

2. Openness creates an increase in the exchanges, thus creating extra national wealth. In order to achieve a perfect economic development, it is imperative to develop the size of markets.

So it is seen that there is channels through which both trade and growth can cause each other. This causation has been extensively studied and both stances have been evidenced in literature. Some researchers find that more trade stimulates economic growth (Balassa 1978; Baldwin 1963; Bhala and Lau 1991; Keesing 1974; Krueger 1980; Meier 1984; Michaely 1977; Tyler 1981); some has found evidences to the contrary (Myrdal 1957; Nurkse 1961; Prebisch 1962; Singer 1964). Some studies have found that there is bi-directional causality between trade and growth, such as Chow (1987) and Anoruo and Ahmad (2000). No causal relationship has also been evidenced in some studies, such as Jung and Marshall (1985), Abhayaratne (1996), Sinha and Sinha (1996), Guillaumet and Richaud (2001) and Cuadros, Orts and Alguacil (2004). Therefore, like finance-growth, trade-growth debate does not reach to any single conclusion.

Unlike finance-growth and trade-growth debates, trade-finance debate is comparatively less pronounced. Little empirical research has been carried out in this area. Well-developed financial sector may act as an incentive to the export and import industries. Financial sector channel savings into private sector and thus help overcome liquidity constraints, which enables the economy to specialize and exploit economies of scale. Lower cost of and easy accessibility to obtaining export and import financing induce entrepreneurs to initiate profitable projects. Thus financial development may cause trade openness. Kletzer and Bardhan (1987) first propose that countries with a relatively well-developed financial sector have a comparative advantage in industries and sectors that rely on external finance. This may be called a supply driven phenomenon. The causal effect may also run from the opposite direction. Increased volume of trade may act as an impulse for financial sector to grow. Trade openness by increasing the efficiency of technology (through knowledge spillovers) 
might increase the payoff to financing young entrepreneurs, fostering the formation of active capital markets and avoiding "low growth trap" equilibria (Ginebri, Petrioli and Sabani, 2001).

Although causal link between trade and growth, growth and finance, and finance and trade have been examined theoretically as well as empirically, research combining finance, growth and trade seems to have not been received that much attention in empirical research. This paper attempts to investigate this causal relationship among economic growth, trade openness and financial development in Bangladesh.

\section{Rationale of the Study}

Bangladesh is one of the poorest countries in the world. Over the last decade Bangladesh has made little progress in reducing poverty. Population below national poverty line has been decreased from 51 percent in 1995-96 to 49.80 percent in 2000. Compared with the magnitude of poverty this progress is insignificant. As per international poverty line, 36 percent of its population still lives on $\$ 1 /$ day or less and nearly half of its population lives below national poverty line. Moreover, share of the poorest quintile in the national income decreased from 9.5 percent in 1988-89 to 9.00 in 2000 (see Table-1). Bangladesh is one of the countries that have failed to make reasonable progress in achieving target to reduce hunger (one of the dimensions of poverty) within 2015 as one of the Millennium Development Goals (MDGs) (UNCDAT, 2004).

Table1: Poverty in Bangladesh

\begin{tabular}{cccc}
\hline $\begin{array}{c}\text { Survey } \\
\text { Year }\end{array}$ & $\begin{array}{c}\text { Population } \\
\text { below \$1/day }\end{array}$ & $\begin{array}{c}\text { Population below } \\
\text { national poverty line }\end{array}$ & $\begin{array}{c}\text { Share of poorest quintile in } \\
\text { national consumption or income }\end{array}$ \\
\hline 1986 & & & $9.50^{*}$ \\
$1995-96$ & & 51.00 & 9.00 \\
2000 & $36 \%$ & 49.80 & \\
\hline
\end{tabular}

Source: World Development Indicator, 2004, * World Development Report, 1993.

In this backdrop it is necessary to identify the effect of trade openness and financial development on economic growth. Empirical researches suggest that trade openness, through its growth enhancing effect, can play important role in reducing poverty (Agénor 2002; Chen, Ranaweera and Storozhuk 2004; Dollar and Kraay 2001; Gallup, Radelet and Warner 1999; Nicita 2004; Porto 2004 and 2003). Similarly financial development also plays important role in reducing poverty. Empirical studies find that financial development reduces poverty through its positive impact on economic growth (Beck, Demirg $\ddot{u}$ c-Kunt and Levine 2004; Jalilian and Kirkpatrick 2005). Therefore, Trade openness and financial development can play significant role in reducing poverty and they should have positive impact on economic growth.

Economic growth is an indirect channel through which trade openness and financial development contribute to poverty reduction. Besides, there are direct channel through which these two macroeconomic indicators help reduce poverty. Through direct channel trade openness creates employment. Higher volume of trade means higher production and higher production gives rise to higher employment and income, which reduce poverty. Similarly financial development directly and positively affects poverty reduction by increasing the accessibility to credit and facilitating saving mobilization of the poor. Financial development and trade openness can contribute to poverty reduction through their causal impact on each other. Therefore, from the viewpoint of direct and indirect poverty-reducing role of trade openness and financial development it is of essence to examine the casual relationship among economic growth, trade openness and financial development.

\section{Objectives of the Study}

This paper aims at drawing inference about the effectiveness of trade openness and financial development in reducing poverty in Bangladesh. In doing so the paper relies on the findings of previous research that economic growth reduces poverty and examines whether trade openness and financial development positively affect economic growth. If it were, then the inference would be that 


\section{The Journal of Nepalese Business Studies}

These two reduce poverty indirectly through their growth enhancing effect. Although both trade openness and financial development have causal impact on growth, an isolated analysis of causal impact of each of these two on growth would impede a clear identification of the causal links among financial development, trade openness and growth. Accordingly the objective of this paper is to identify the causal links between these three macroeconomic variables in Vector Auto-Regressive (VAR) framework for Bangladesh. To be specific, the objectives are to examine whether, in Bangladesh,

a. Trade openness and financial development have causal effects on economic growth;

b. Trade openness and economic growth have causal effects on financial development; and

c. Economic growth and financial development have causal effects on trade openness.

\section{Methodology}

This paper employs Granger-causality test in Vector Auto Regression (VAR) framework to examine causal relationship among trade openness, financial development and economic growth in Bangladesh. Description of data is presented first, and then procedure to examine stationarity of underlying time series is described. Next, Johansen cointegration test is described followed by Granger-causality methodology in VAR and finally the section is concluded with the discussion on stability of the estimated VAR.

\subsection{Data}

Present study examines the causal relationship among financial development, trade openness and economic growth in Bangladesh using annual data from 1974 to 2003. Three proxies of financial development are used: private credit as a percentage of Gross Domestic Product (GDP) (hereafter PC), domestic credit as a percentage of GDP (hereafter DC) and broad money as a percentage of GDP (hereafter M). The sum of export and import as a percentage of GDP is used as a measure of trade openness (hereafter TO). Growth rate of real per capita GDP is used as the indicator of economic growth (hereafter GR). Real GDP is obtained by deflating nominal GDP by GDP deflator $(2000=100)$. All data are taken from IFS-2004, CD-ROM version.

\subsection{Stationarity of Time Series}

One applied method to investigate causal relationship between variables empirically is Granger-causality analysis. Causality in the sense Granger (1969) is inferred when values of a variable, say, $x_{t}$, have explanatory power in a regression of $y_{t}$ on lagged values of $y_{t}$ and $x_{t}$. If lagged values of $x_{t}$ have no explanatory power for any of the variables in the system, then $x$ is viewed as weakly exogenous to the system. The present study will test for Granger-causality relationship among trade openness, financial development and economic growth. The conventional Granger-causality test based on standard VAR is conditional on the assumption of stationarity of the variables constituting the VAR. If the time series are non-stationary, the stability condition of VAR is not met, implying that the Wald $\chi^{2}$ test statistic for Granger-causality is invalid. In this case cointegration and Vector Error Correction Model (VECM) are recommended to investigate the relationship between non-stationary variables. Therefore, before proceeding any further it is imperative to ensure that the underlying data are stationary or I (0). 'A time series is said to be stationary if its mean and variance are constant over time and value of covariance between two time periods depends only on the distance or lag between the two time periods and not on the actual time at which covariance is computed' (Gujarati 1995). Augmented Dickey-Fuller (ADF) test is used to check whether the underlying series contain unit roots. ADF statistic is obtained by

$$
\Delta x=a_{0}+b_{0} x_{t-1}+\sum_{i=1}^{k} c_{0} \Delta x_{t-1}+w_{t}
$$


Where, $\Delta$ is the difference operator, $a_{0}, b_{0}$, and $c_{0}$ are coefficients to be estimated, $x$ is the variable whose time aeries properties to be examined and $w$ is the white-noise error term. The lags of dependent variable to obtain serially uncorrelated white-noise residual are empirically determined by Schwarz criterion (SC).

If the underlying series contain unit root i.e. are not I (0), but, say, I (1), then the Granger representation theorem requires that they must be co-integrated that is their linear combination must be I (0). Therefore the next step is to examine the variables for cointegration.

\subsection{Cointegration test}

Engel and Granger (1987) pointed out that a linear combination of two or more non-stationary variables may be stationary. If such a stationary combination exists, then the non-stationary time series are said to be co-integrated. The VAR based co-integration test using the methodology developed in Johansen $(1991,1995)$ is described below.

Consider a VAR of order $p$

$$
y_{t}=A_{1} y_{t-1}+\cdots+A_{p} y_{t-p}+B x_{t}+\varepsilon_{t}
$$

Where, $y_{t}$ is a $k$-vector of non-stationary I (1) variables, $x_{t}$ is a $d$-vector of deterministic variables and $\varepsilon_{t}$ is a vector of innovations. This VAR can be rewritten as follows:

$$
\Delta y_{t}=\prod y_{t-1}+\sum_{i=1}^{p-1} \Gamma_{i} \Delta y_{t-i}+B x_{t}+\varepsilon_{t}
$$

Where, $\Pi=\sum_{i=1}^{p} A_{i}-I$, and $\Gamma=-\sum_{j=i+1}^{p} A_{j}$

Granger representation theorem asserts that if the coefficient matrix $\prod$ has reduced rank $r<k$, then there exists $k \times r$ matrices $\alpha$ and $\beta$ each with rank $r$ such that $\Pi=\alpha \beta^{\prime}$ and $\beta^{\prime} y_{t}$ is $\mathrm{I}(0)$. Johansen's method is to estimate the $\prod$ matrix from an unrestricted VAR and to test the null hypothesis that the restriction implied by the reduced rank of $\Pi$ can be rejected against the alternative hypothesis that the matrix $\prod$ has full rank. Johansen procedure provides two statistics, one is LR test based on the maximum eigenvalue of the stochastic matrix and the value of the LR test based on the stochastic matrix.

\subsection{VAR and Granger-causality}

One implication of Granger representation theorem is that if two variables, say $X_{t}$ and $Y_{t}$ are cointegrated and each is individually I(1), then either $X_{t}$ must Granger-cause $Y_{t}$ or $Y_{t}$ must Grangercause $X_{t}$. This causality of cointegrated variables is captured in Vector Error Correction Model (VECM). In a VECM long and short-run parameters are separated. In the present study linear combinations of non-stationary variables are not found stationary, that is, the variables are not cointegrated. In absence of cointegration the unrestricted VAR in first difference is estimated, which take the following form:

$$
\Delta Y_{t}=\sum_{i=1}^{n} b_{1 i} \Delta Y_{t-i}+\sum_{i=1}^{n} c_{1 i} \Delta X_{t-i}+\sum_{i=1}^{n} d_{1 i} \Delta Z_{t-i}+e_{1 t}
$$




$$
\begin{gathered}
\Delta X_{t}=\sum_{i=1}^{n} b_{2 i} \Delta Y_{t-i}+\sum_{i=1}^{n} c_{2 i} \Delta X_{t-i}+\sum_{i=1}^{n} c_{2 i} \Delta Z_{t-i}+e_{2 t} \\
\Delta Z_{t}=\sum_{i=1}^{n} b_{3 i} \Delta Y_{t-i}+\sum_{i=1}^{n} c_{3 i} \Delta X_{t-i}+\sum_{i=1}^{n} d_{3 i} \Delta Z_{t-i}+e_{3 t}
\end{gathered}
$$

Where, $\Delta$ is the first difference operator; $e_{1 t}, e_{2 t}, e_{3 t}$ are random disturbances and $n$ is the number of optimum lag length, which is determined empirically by Schwarz criterion (SC). For each equation in the above VAR, Wald $\chi^{2}$ statistics is used to test the joint significance of each of the other lagged endogenous variables in that equation. For $\Delta Y_{t}$ to be unaffected by $\Delta X_{t}$ and $\Delta Z_{t}, \sum c_{1 i}$ and $\sum d_{1 i}$ respectively must not be significantly different from zero. Similar logic applies to $\Delta X_{t}$ and $\Delta Z_{t}$.

\subsection{Stability of VAR}

In order for the conclusions drawn from the above system, it is necessary that the VAR be stable or stationary. If the estimated VAR is stable then the inverse roots of characteristics Autoregressive (AR) polynomial will have modulus less than one and lie inside the unit circle. There will be $k p$ roots, where $k$ is the number of endogenous variables and $p$ is the largest lag.

\section{Results}

This section presents results of empirical analyses of the paper. Unit root test result is reported first followed by Johansen cointegration test result. Next Granger-causality test result is presented and finally stability of the estimated VAR is examined.

\subsection{Unit Root Test}

Estimation procedure starts with examining stationarity of underlying time series data. ADF result is reported in Table-2. Test results show that none of the variables are level stationary, but first difference of all them are stationary, that is all variables are I(1).

Table2: ADF Test

\begin{tabular}{lcccc}
\hline Variables & \multicolumn{2}{c}{ Level } & \multicolumn{2}{c}{ First Difference } \\
\cline { 2 - 5 } & Intercept & Intercept \& Trend & Intercept & $\begin{array}{c}\text { Intercept \& } \\
\text { Trend }\end{array}$ \\
\hline GR & $-1.99075(3)$ & $-2.90766(1)$ & $-8.50946 *(1)$ & $-9.86824^{*}(1)$ \\
DC & $-1.7065(1)$ & $-2.0816(1)$ & $-4.50^{*}(1)$ & $-4.40^{*}(1)$ \\
PC & $-1.1464(1)$ & $-2.3083(1)$ & $-3.4135^{* *}(1)$ & $-3.3495^{* * *}(1)$ \\
TO & $-0.2255(3)$ & $-2.6181(3)$ & $-4.8187 *(2)$ & $-4.8329 *(1)$ \\
M & $-1.9215(2)$ & $-3.1025(1)$ & $-4.9448^{*}(1)$ & $-4.8363 *(1)$ \\
\hline
\end{tabular}

1. $\quad * * *$, and $* * *$ indicates significant at $1 \%, 5 \%$ and $10 \%$ level.

2. Figures in parentheses indicate optimum lag length determined by SC.

\subsection{Johansen Co-integration Test}

Results of Johansen cointegration test between GR and TO and three measures of financial development, DC, PC and M are reported in Table-3.1 through Table-3.3. In each case both trace statistic and maximum eigenvalue statistic are below the critical values at $1 \%$ and $5 \%$ significance level suggesting that there is no cointegrating relations between GR, TO and different measures of financial development. 
Temporal Causality and Dynamics of Financial Development

Table 3.1: Johansen Cointegration Test between GR, TO and DC

\begin{tabular}{lcccccc}
\hline $\begin{array}{l}\text { Null } \\
\text { Hypotheses }\end{array}$ & $\begin{array}{c}\text { Trace } \\
\text { statistic }\end{array}$ & $\begin{array}{c}1 \% \text { critical } \\
\text { value }\end{array}$ & $\begin{array}{c}5 \% \\
\text { critical } \\
\text { value }\end{array}$ & $\begin{array}{c}\text { Max-Eigen } \\
\text { value }\end{array}$ & $\begin{array}{c}1 \% \text { critical } \\
\text { value }\end{array}$ & $\begin{array}{c}5 \% \\
\text { critical } \\
\text { value }\end{array}$ \\
\hline$r=0$ & 21.95988 & 41.07 & 34.91 & 15.04039 & 26.81 & 22.00 \\
$r \leq 1$ & 6.919487 & 24.60 & 19.96 & 4.712201 & 20.20 & 15.67 \\
$r \leq 2$ & 2.207286 & 12.97 & 9.24 & 2.207286 & 12.97 & 9.27 \\
\hline
\end{tabular}

Table 3.2: Johansen Cointegration Test between GR, TO and PC

\begin{tabular}{lcccccc}
\hline $\begin{array}{l}\text { Null } \\
\text { Hypotheses }\end{array}$ & $\begin{array}{c}\text { Trace } \\
\text { statistic }\end{array}$ & $\begin{array}{c}1 \% \\
\text { critical } \\
\text { value }\end{array}$ & $\begin{array}{c}5 \% \\
\text { critical } \\
\text { value }\end{array}$ & $\begin{array}{c}\text { Max-Eigen } \\
\text { value }\end{array}$ & $\begin{array}{c}1 \% \\
\text { critical } \\
\text { value }\end{array}$ & $\begin{array}{c}5 \% \\
\text { critical } \\
\text { value }\end{array}$ \\
\hline$r=0$ & 33.54085 & 41.07 & 34.91 & 21.99188 & 26.81 & 22.00 \\
$r \leq 1$ & 11.54896 & 24.60 & 19.96 & 8.102776 & 20.20 & 15.67 \\
$r \leq 2$ & 3.446188 & 12.97 & 9.24 & 3.446188 & 12.97 & 9.27 \\
\hline
\end{tabular}

Table 3.3: Johansen Cointegration Test between GR, TO and M

\begin{tabular}{lcccccc}
\hline $\begin{array}{l}\text { Null } \\
\text { Hypotheses }\end{array}$ & $\begin{array}{c}\text { Trace } \\
\text { statistic }\end{array}$ & $\begin{array}{c}1 \% \\
\text { critical } \\
\text { value }\end{array}$ & $\begin{array}{c}5 \% \text { critical } \\
\text { value }\end{array}$ & $\begin{array}{c}\text { Max-Eigen } \\
\text { value }\end{array}$ & $\begin{array}{c}1 \% \\
\text { critical } \\
\text { value }\end{array}$ & $\begin{array}{c}5 \% \text { critical } \\
\text { value }\end{array}$ \\
\hline$r=0$ & 28.46600 & 41.07 & 34.91 & 18.71087 & 26.81 & 22.00 \\
$r \leq 1$ & 9.755131 & 24.60 & 19.96 & 7.860307 & 20.20 & 15.67 \\
$r \leq 2$ & 1.894823 & 12.97 & 9.24 & 1.894823 & 12.97 & 9.27 \\
\hline
\end{tabular}

\subsection{Granger-causality Test}

Having found no cointegrating relationship between GR, TO and three measures of financial development, Granger-causality test in first difference VAR is carried out next and the results are reported in Table 4.1 through Table 4.3. According to Schwarz criterion one lag order is found appropriate for each case (not reported here). The first column of each table defines the dependent variables; second to fourth columns display Wald $\chi^{2}$ statistics for the joint significance of each of the other lagged endogenous variables with their associated probabilities in parentheses.

Granger-causality results based on first difference VAR reported in Table 4.1 suggest that the null hypotheses that $\triangle T O$ and $\triangle D C$ do not Granger cause $\triangle G R$ are not rejected, which indicates absence of causality from $\triangle T O$ and $\triangle D C$ to $\triangle G R$. In $\triangle T O$ equation $\triangle D C$ does not Granger cause $\triangle T O$ hypothesis is rejected at $10 \%$ level, but the hypothesis that $\Delta G R$ does not Granger-cause $\triangle T O$ is not rejected. In $\triangle D C$ equation the hypothesis that $\triangle G R$ does not Granger-cause $\triangle D C$ is not rejected but $\triangle T O$ does not Granger-cause $\triangle D C$ is rejected at $10 \%$. So, there is bi-directional or feedback causality between $\triangle D C$ and $\triangle T O .00000$ 
The Journal of Nepalese Business Studies

Table 4.1: VAR pair-wise Granger-causality between $\triangle D C, \triangle T O$ and $\triangle D C$

\begin{tabular}{lccc}
\hline \multirow{2}{*}{$\begin{array}{l}\text { Dependent } \\
\text { variable }\end{array}$} & \multicolumn{3}{c}{ Short-run Causality, Wald $\chi^{2}$ statistic (probability) } \\
\cline { 2 - 4 } & $\Delta G R$ & $\Delta T O$ & $\Delta D C$ \\
\hline$\Delta G R$ & & 0.767734 & 0.000171 \\
& & $(0.3809)$ & $(0.9896)$ \\
$\Delta T O$ & 0.798154 & & 2.971305 \\
& $(0.3716)$ & & $(0.0848)^{* * *}$ \\
$\Delta D C$ & 0.016881 & 3.120667 & \\
\hline dicates significant at $10 \%$ level. & $(0.8966)$ & $(0.0773)^{* * *}$ & \\
\hline
\end{tabular}

*** Indicates significant at $10 \%$ level.

Granger-causality results, taking into account another proxy for financial development, PC, are reported in Table 4.2. In $\triangle G R$ equation, the hypotheses of Granger non-causality from $\triangle T O$ and $\triangle P C$ are not rejected. Like $\triangle G R$ equation, in $\triangle T O$ equation too Granger non-causality hypotheses for $\triangle G R$ and $\triangle P C$ are not rejected. In $\triangle P C$ equation the hypotheses that $\triangle G R$ and $\triangle T O$ do not Granger-cause $\triangle P C$ are not rejected.

Table 4.2: VAR pair-wise Granger-causality between $\triangle D C, \triangle T O$ and $\triangle P C$

\begin{tabular}{lccc}
\hline \multirow{2}{*}{$\begin{array}{l}\text { Dependent } \\
\text { variable }\end{array}$} & \multicolumn{3}{c}{ Short-run Causality, Wald $\chi^{2}$ statistic (probability) } \\
\cline { 2 - 4 } & $\Delta G R$ & $\Delta T O$ & $\Delta P C$ \\
\hline$\Delta G R$ & & 1.441906 & 0.117972 \\
& & $(0.2298)$ & $(0.7312)$ \\
$\Delta T O$ & 0.332659 & & 0.012824 \\
& $(0.5641)$ & & $(0.5641)$ \\
$\Delta P C$ & 0.164970 & 0.253987 & \\
& $(0.6846)$ & $(0.6143)$ & \\
\hline
\end{tabular}

Table 4.3 presents Granger-causality test results between $\Delta G R, \Delta T O$ and $\Delta M$. The results suggest that in $\triangle G R$ equation the null hypothesis of no Granger causality from $\triangle T O$ and $\triangle M$ to $\triangle G R$ are not rejected. In $\Delta T O$ equation the hypothesis that $\triangle G R$ does not Granger cause $\triangle T O$ is not rejected, but the hypothesis that $\Delta M$ does not Granger cause $\Delta T O$ is rejected at $10 \%$ level. In $\Delta M$ equation, null hypotheses that $\Delta G R$ and $\Delta T O$ do not Granger cause $\Delta M$ are not rejected. So, one-way causality is found from $\Delta M$ to $\triangle T O$ in this system of VAR.

Table 4.3: VAR pair-wise Granger-causality between $\triangle D C, \triangle T O$ and $\triangle D M$

\begin{tabular}{lccc}
\hline Dependent & \multicolumn{3}{c}{ Short-run Causality, Wald $\chi^{2}$ statistic (probability) } \\
\cline { 2 - 4 } variable & $\Delta G R$ & $\Delta T O$ & $\Delta M$ \\
\hline$\Delta G R$ & & 0.332922 & 1.048464 \\
& & $(0.5639)$ & $(0.3059)$ \\
$\Delta T O$ & 0.200473 & & 3.292273 \\
& $(0.6543)$ & & $(0.0696)^{* * *}$ \\
$\Delta M$ & 0.096084 & 0.462446 & \\
& $(0.7566)$ & $(0.4965)$ & \\
\hline
\end{tabular}

*** Indicates significant at $10 \%$ level. 
Temporal Causality and Dynamics of Financial Development

\subsection{Stability of VAR}

Stability of the estimated VARs is examined by checking the Roots of Characteristic Polynomial, which is reported in Table 5. As each VAR has one lag and three endogenous variables, there are three roots in each case. According to the results reported in Table 4, moduli of all roots are less than unity and lie within the unit circle. So the estimated VARs are stable or stationary.

Table 5: Roots of Characteristic Polynomial

\section{Findings}

\begin{tabular}{lll}
\hline Variables in VAR & Root & Modulus \\
\hline \multirow{2}{*}{$\Delta$ GR, $\Delta$ TOand $\Delta D C$} & -0.751287 & 0.751287 \\
& $-0.049194-0.320878 \mathrm{i}$ & 0.324627 \\
& $-0.049194+0.320878 \mathrm{i}$ & 0.324627 \\
\hline \multirow{3}{*}{$\Delta$ GR, $\Delta$ TOand $\Delta P C$} & -0.756317 & 0.756317 \\
& 0.221577 & 0.221577 \\
& -0.091310 & 0.091310 \\
\hline \multirow{3}{*}{ GR, $\Delta$ TOand $\Delta M$} & -0.715797 & 0.715797 \\
& $-0.035357-0.154771 \mathrm{i}$ & 0.158758 \\
& $-0.035357+0.154771 \mathrm{i}$ & 0.158758 \\
\hline
\end{tabular}

Findings of the previous section's analysis are summarized as under:

1. No causal relationship between trade openness and economic growth is evidenced. These two variables are found independent implying lack of support in favour of trade-led growth and growth-led trade.

2. The study also finds that the level of financial development and economic growth are not causally related. That is, in this case too, no evidence is found in favour of either finance led growth or growth led finance.

3. Evidence of some causal relationship is found between trade openness and financial development. Bi-directional or feedback Granger-causality is evidenced between trade openness and financial development measured by the domestic credit as a percentage of GDP. One-way causality is found running from broad money as a percentage of GDP to trade openness.

In addition to the direction of causality, Garrett (2001) points that the distinction between the short run and long run nature of variables seems to be very relevant. Within the time series context, given that all variables are first difference stationary, the existence of a long-run relationship between these variables will manifest itself through cointegration between their levels. As Johansen cointegration test suggest that there is no cointegrating relationship between variables under the study, we conclude that growth, trade openness and financial development do not have any long-run equilibrium relationship.

\section{Conclusions}

This paper examines temporal causality among financial development, trade openness and economic growth in Bangladesh over the period from 1974 to 2003. Estimation procedure starts with examining stationarity property of the underlying time series data. ADF unit root test results suggest that the variables are non-stationary at level, but stationary at their first differences. Johansen cointegration test results show that although the variables are first difference stationary, there is no cointegrating relationship between them. In absence of cointegration, Granger causality test is carried out in first difference VAR. For each VAR one lag length is applied as suggested by SC.

Granger-causality results suggest that trade openness and growth, and growth and financial development are independent. That is trade openness and financial development do not have any causal impact on economic growth; conversely growth does not have any causal impact on trade and financial development. However, evidence is found to support finance-trade nexus. Domestic credit 


\section{The Journal of Nepalese Business Studies}

and broad money, both as a percentage of GDP have causal impact on economic growth. On the other hand, trade has causal impact on only domestic credit.

The findings of the study imply that trade and financial development do not have any positive effect on reduction of poverty through their effect on economic growth. But as there is causal relationship between trade openness and financial development, they indirectly contribute to poverty reduction through their causal effect on each other in addition to their direct positive effect on poverty reduction.

Policy implication of this result would be to take both trade openness and financial development as policy variables to accelerate the speed of integration of domestic market with the world economy and to further the development of financial sector in order for these two macro aspects to contribute poverty reduction through their direct as well as indirect link to poverty.

\section{REFERENCES}

Abhayaratne, Anoma S.P. 1996. Foreign Trade and Economic Growth: Evidence from Sri Lanka 1960-92. Applied Economic Letter 3: 567-570.

Agénor, Pierre-Richard. 2002. "Macroeconomic Adjustment and the Poor: Analytical Issues and Cross-Section Evidence." Policy Research Working Paper no.2788, The World Bank.

Anoruo, Emmanuel and Yusuf Ahmad. 2000. Openness and Economic Growth: Evidence from Selected ASEAN Countries. The Indian Economic Journal 47:110-117.

Balassa, Bela. 1978. Exports and Economic Growth: Further Evidence. Journal of Development Economics 5:181-189.

Baldwin, R. 1963. Exports, Technology and Development from a Subsistence Level. Economic Journal 73:80-92.

Beck, Thorsten; Asli Demirg $\ddot{u}$ c-Kunt and Ross Levine. 2004. "Finance, Inequality and Poverty." Policy Research Working Paper no. 3338, The World Bank.

Berthelemy, J.C. and A. Varoudakis. 1996. "Models of Financial Development and Growth: A Survey of Recent Literature" in Hermes, N and R. Lensink (eds), Financial Development and Economic Growth: Theory and Experiences from Developing Countries: 7-29. London: Routledge.

Bhala, Surgit and Lawrence J. Lau. 1991. "Openness, Technological Progress and Economic Growth in Developing Countries" Background Paper for World Development Report 1991.

Chen, Derek H.C., Ranaweera, Thilak and Storozhuk, Andriy. 2004. "The RMSM-X+P. A Minimal Poverty Module for the RMSM-X" Policy Research Working Paper no.3304, The World Bank.

Chow, P.C.Y. 1987. Causality between Export and Industrial Development: Empirical Evidence from NICs. Journal of Development Economics 26: 55-63.

Cuadros, A., V. Orts and M.T. Alguacil. 2004. "Openness and Growth: Re-Examining Foreign Direct Investment, Trade and Output Linkages in Latin America" Working Paper no.01/04, Centre for Research in Economic Development and Trade Openness (CREDIT), University of Nottingham, U.K.

Dollar, David and Kraay, Aart. 2001. "Trade, Growth and Poverty" Policy Research Working Paper no. 2615, The World Bank.

Engle, R.F. and C.W.J. Granger. 1987. Co-integration and Error Correction: Representation, Estimation and Testing. Econometrica 55: 251-276.

Gallup, John Luke; Radelet, Steven and Warner, Andrew (1999), "Economic Growth and the Income of the Poor" Consulting Assistance for Economic Reform II (CARE II) Discussion Paper no. 36. Harvard Institute for International Development.

Garcia, V.F. and L. Liu.1999. Macroeconomic Determinant of Stock Market Development. Journal of Applied Economics 2:29-59.

Garrett, G. 2001. Globalization and Government Spending Around the World. Studies in Comparative International Development 35:3-29. 
Ginebri, Sergio, Giacomo Petrioli and Laura Sabani. 2001. "Financial Deepening, Trade Openness and Growth: a Multivariate Cointegrated Analysis of the Complementary Effects" CIDEI Working paper no.62.

Graff, M. 2001. "Financial Development and Economic Growth in Corporatist and Liberal Market Economies" paper presented at the $30^{\text {th }}$ Annual Conference of Economists, Parth, September $24^{\text {th }}$.

Granger, C.W.J. 1969. Investigating Causal Relations by Econometric Models and Cross-Spectral Models. Econometrica :424-438.

Guillaumet, Philippe and Alain Richaud. 2001. "Openness and Economic Growth: The Case of France Since 1850" paper presented at VI ${ }^{\text {th }}$ Spring Meeting of Young Economists, 30 March-1 April, University of Copenhagen, Denmark.

Gujarati, N. Damodar. 1995. Basic Econometrics, 3rd ed. New Delhi: McGraw-Hill, Inc.

Jalilian, Hossain and Colin Kirkpatrick. 2005. Does Financial Development Contribute to Poverty Reduction? The Journal of Development Studies 41:636-656.

Johansen, Sǿren. 1991. Estimation and Hypothesis Testing of Cointegration Vectors in Gaussian Vector Autoregressive Models. Econometrica 59:1551-1580.

Johansen, Sǿren. 1995. Likelihood-based Inference in Cointegrated Autoregressive Models. Oxford: Oxford University Press.

Jung, Woo S. and Peyton J. Marshall. 1985. Exports, Growth and Causality in Developing Countries. Journal of Developing Development Economics 18:1-12.

Keesing, D. 1974. Income Distribution from Outward-Looking Policies. The Pakistan Development Review 13:188-204.

King, R. and Levine, Ross. 1993a. Finance, Entrepreneurship and Growth: Theory and Evidence. Journal of Economics 32:513-542.

King, R. and Levine, Ross. 1993b. "Financial Intermediation and Economic Development" in Mayer, C. and X. Vives (Eds.), Capital Markets and Financial Intermediation. London: Center for European Economic Policy Research.

King, R. and Levine, Ross. 1993c. Finance and Growth: Schumpeter Might Be Right. Quarterly Journal of Economics 108(3): 717-37.

King, R. G. and Levine, Ross. 1992. "Financial Indicator and Economic Growth in a Cross Section of Countries" PRE Working Paper no. 819 (Washington: World Bank).

Kletzer, K. and P. Bardhan. 1987. Credit Markets and Patterns of Trade openness. Journal of Development Economics 27: 57-70.

Krueger, Anne. 1980. Foreign Trade Regimes and Economic Development: Liberalization attempts and consequences. Cambridge, MA: Ballinger Pub. Co. for NBER.

Levine, Ross. 2003. More on Finance and Growth: More Finance, More Growth? Review, Federal Reserve Bank of St. Louis 85:31-46.

Lucas, Robert E. Jr. 1988. On the Mechanics of Economic Development. Journal of Monetary Economics 22:3-42.

McKinnon, Ronald. 1973. Money and Capital in Economic Development. Washington, D.C: The Brooking institution.

Meier, G.M. 1984. Leading Issues in Economic Development. New York: Oxford University Press.

Meier, Gerald M. and Seers, Dudley. 1984. Pioneers in Development. Oxford: Oxford University Press.

Michaely, Micheal. 1977. Exports and Growth: An Empirical Investigation. Journal of Development Economics 4:49-54.

Miller, Merton H. 1998. Financial Markets and Economic Growth. Journal of Applied Corporate Finance 11:8-14.

Miller, Stephen and Frank S. Russek. 1990. Co-integration and Error Correction Model: The Temporal Causality between Government Taxes and Spending. Southern Economic Journal: 221-229.

Myrdal, G. 1957. Economic Theory and Underdevelopment Regions, London. 
Narayan, Paresh Kumar and Russel Smyth. 2004. Temporal Causality and the Dynamics of Exports, Human Capital and Real Income in China. International Journal of Applied Economics 1:24-45.

Nicita, Alessandro. 2004. "Who Benefited from Trade Liberalization in Mexico? Measuring the Effects on Household Welfare." Policy Research Working Paper no. 3265, The World Bank

Nurkse, R. 1957. "Trade Theory and Development Policy" in H.S. Ellis (ed.), Economic Development of Latin America, New York: St. Martin Press.

Patrick, H.T. 1966. Financial Development and Economic Growth in Underdeveloped Countries. Economic Development and Cultural Change 14:174-189.

Porto, Guido G. 2003. "Trade Reforms, Market Access and Poverty in Argentina" Policy Research Working Paper no. 3135, The World Bank.

Porto, Guido G. 2004. "Informal Export Barriers and Poverty" Policy Research Working Paper no. 3354, The World Bank.

Prebisch, A. 1962. Economic Development of Latin America and Its Principal Problem. Economic Bulletin for Latin America 7:223-227.

Shaw, E. 1973. Financial Deepening in Economic Development,. Oxford: Oxford University Press.

Sims, C. 1980. Macroeconomics and Reality. Econometrica 48:1-49.

Singer, H.W. 1964. International Development: Growth and Change. New York: McGrawHill.

Sinha, Dipendra and Tapen Sinha. 1996. Openness and Economic Growth: Time Series Evidence From India. Applied Economics 9:121-130.

Tyler, W.B. 1981. Growth and Export Expansion in Developing Countries. Journal of Development Economics 9: 121-130. 